Research Article

\title{
Enhancing Enzymatic Digestibility of Coconut Husk using Nitrogen-assisted Subcritical Water for Sugar Production
}

\author{
Maktum Muharja1, Nur Fadhilah ${ }^{2}$, Tantular Nurtono ${ }^{1}$, Arief Widjaja ${ }^{1, *}$ \\ ${ }^{1}$ Department of Chemical Engineering, Sepuluh Nopember Institute of Technology, Sukolilo, \\ Surabaya East Java 60111 Indonesia \\ ${ }^{2}$ Department of Engineering physics, Sepuluh Nopember Institute of Technology, Sukolilo, \\ Surabaya East Java 60111 Indonesia
}

Received: 1st July 2019; Revised: 27th September 2019; Accepted: 27th September 2019; Available online: $28^{h}$ February 2020; Published regularly: April 2020

\begin{abstract}
Coconut husk $(\mathrm{CCH})$ as an abundant agricultural waste in Indonesia has the potential to be utilized for sugar production, which is the intermediate product of biofuel. In this study, subcritical water (SCW) assisted by nitrogen $\left(\mathrm{N}_{2}\right)$ was developed to enhance the enzymatic hydrolysis of CCH. SCW process was optimized by varying the operation condition: the pressure of 60-100 bar, the temperature of 150-190 ${ }^{\circ} \mathrm{C}$, and the time of 20-60 min. The SCW-treated solid was subsequently hydrolyzed by utilizing a mixture of commercial cellulase and xylanase enzymes. The result shows that the optimum total sugar yield was obtained under the mild condition of SCW treatment, resulting in the sugar of $15.67 \%$ and $10.31 \%$ gained after SCW and enzymatic hydrolysis process, respectively. SEM and FTIR analysis of SCW-treated solid exhibited the deformation of lignin and solubilization of cellulose and hemicellulose, while XRD and TGA revealed an increase of the amount of crystalline part in the solid residue. The use of $\mathrm{N}_{2}$ in SCW treatment combined with enzymatic hydrolysis in this study suggested that the method can be considered economically for biofuel production from $\mathrm{CCH}$ waste in commercial scale. Copyright (C) 2020 BCREC Group. All rights reserved
\end{abstract}

Keywords: coconut husk; subcritical water; enzymatic hydrolysis; sugar production

How to Cite: Muharja, M., Fadhilah, N., Nurtono, T., Widjaja, A. (2020). Enhancing Enzymatic Digestibility of Coconut Husk using Nitrogen-assisted Subcritical Water for Sugar Production. Bulletin of Chemical Reaction Engineering \& Catalysis, 15(1): 84-95 (doi:10.9767/bcrec.15.1.5337.84-95)

Permalink/DOI: https://doi.org/10.9767/bcrec.15.1.5337.84-95

\section{Introduction}

Lignocellulose biomass is considered one of the most promising alternative renewable resources for biofuel production due to its high energy security and abundant availability in nature [1-3]. One of the potential lignocellulosic biomass which can be utilized is coconut husk $(\mathrm{CCH})$ waste. The $\mathrm{CCH}$ has a high content of

* Corresponding Author.

E-mail: arief_w@chem-eng.its.ac.id (A. Widjaja);

Telp: +62-31-5946240, Fax: +62-31-5999282 cellulose (26.72\%) and hemicellulose (17.73\%) [4-6]. Furthermore, the magnificent production of $\mathrm{CCH}$ in Indonesia (1 million ton/yr) allows the commercialization of biofuel from this waste [7]. Unfortunately, the complexity of lignocellulose structure and the high content of lignin (41.19\%) in $\mathrm{CCH}$ hamper the bioprocess effectiveness which deals with enzyme / microorganism activity to produce biofuel [8]. Therefore, prior to conversion, $\mathrm{CCH}$ must first be subjected to a pretreatment process in order to break the complex structure. 
In recent years, some pretreatment processes for facilitating enzyme/bacteria to access biomass substrate have been studied progressively [9]. The pretreatment process was applied to cleave the hindrance of biomass convolution and simultaneously guarantee the sufficient release of fermentable sugars to be metabolized to biofuel [10]. Up to date, some technologies using any chemicals, such as acid, base, ionic liquid, etc., is still the option of many researchers to obtain biofuels from lignocellulosic biomass [11-14]. Although the yields are relatively high, the technologies produce many new unwanted waste problems which can actually increase production costs for handling the waste [15].

The subcritical water (SCW) process, as the sophisticated technology with some advantages: short reaction time, ease of handle and environmentally friendly, has been developed intensively [16-18]. Recently, studies about SCW is mainly focused on enhancing reducing sugar production and prevent the formation of inhibitors, which are toxic to several microorganisms that pose a threat to the biofuel producing organisms [19,20]. Modifying the SCW condition (pressure, temperature and reaction time) is one of the factors to obtain the maximum reducing sugar yield. [21-23]. As a challenge, under the extreme treatment condition, it would not only enhance sugar production but also increase the levels and distribution of the secondary products, which will inhibit the process significantly [24,25].

Another key factor affected secondary product forming in SCW process is the type of pressurizing gas [26]. Commonly, carbon dioxide gas $\left(\mathrm{CO}_{2}\right)$ is utilized as the pressurizing gas which can be an acid catalyst $\left(\mathrm{HCO}_{3}\right)$ in the SCW process. The catalyst helps the hydrolysis process of holocellulose [27]. In fact, $\mathrm{CO}_{2}$ is not the only gas that has the potential to increase

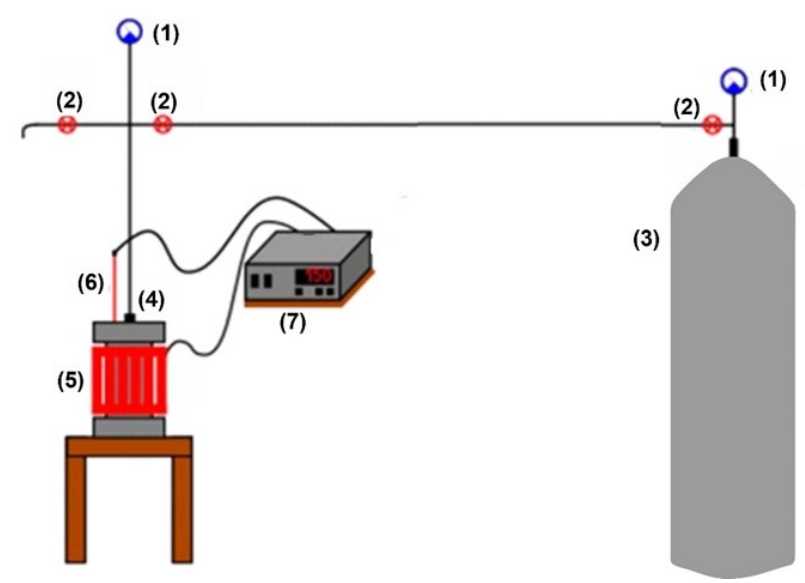

Figure 1. Design of $\mathrm{N}_{2}$-assisted $\mathrm{SCW}$ apparatus. the hydrolysis yield. In the previous study, it has been reported that nitrogen gas $\left(\mathrm{N}_{2}\right)$ had hydrolysis effectiveness as well as $\mathrm{CO}_{2}$ gas. Furthermore, $\mathrm{N}_{2}$ could decrease dramatically Total Organic Carbon (TOC) of biomass compared to $\mathrm{CO}_{2}$ [28]. On the other hand, $\mathrm{N}_{2}$ showed a good hydrolysis performance even at extreme condition because of its inert characteristic [29]. Although having great potential, from the literature studies, there is only a little information about the study of $\mathrm{N}_{2}$ gas performance on the SCW hydrolysis process for sugar production from biomass, especially from coconut husk waste.

To address the aforementioned gap of research, in this work, the performance of SCW assisted by $\mathrm{N}_{2}$ was investigated towards the enhancement of enzymatic hydrolysis. Sugar concentration obtained following SCW and enzymatic hydrolysis was analyzed statistically and discussed comprehensively. Some characterization analysis, by means of Thermogravimetric (TG), Scanning electron microscopy (SEM), X-ray diffraction (XRD), and Fourier transform infrared spectroscopy (FTIR), was also conducted. Finally, the optimum operating condition of SCW assisted by $\mathrm{N}_{2}$ gas is proposed to enhance sugar yield, minimize the operational costs and prevent the side product formation.

\section{Materials and Methods}

\subsection{Materials}

Coconut husk was collected in Manado, North Sulawesi, Indonesia. The preparation procedure of the sample was adapted from $\mathrm{Mu}$ harja et al. [29]. Some chemicals such as Dinitrosalycilic acid (DNS), cellulase from Aspergillus Niger, and xylanase from Trichoderma longibrachiatum were purchased from Sigma Aldrich, Japan.

\subsection{Methods}

\subsubsection{Subcritical water (SCW) process}

The SCW equipment used in this study was modified from previous work [30], as depicted in Figure 1. It consists of two pressure gauge (1), three pressure regulator valve (2), a nitrogen gas cylinder (3), a stainless-steel reactor (4), a jacket heater (5), a thermocouple (6), and a PID controller (7). The safety of the process at high pressure and temperature was ensured by employing high safety materials for constructing the reactor such as providing highquality stainless steel (SS-316), the use of threaded reactor lid in order to prevent leak- 
age, as well as high quality Swagelok valves able to bear high pressure of up to 344 bar.

The process was run by adding $6 \mathrm{~g}$ coconut husk and $120 \mathrm{~mL}$ distilled water inside the stainless-steel (SS-316) reactor and then supplying the ultra-high purity (UHP) Nitrogen $\left(\mathrm{N}_{2}\right)$ gas (PT. Aneka Gas, Sidoarjo, Indonesia) with varied pressure of 60-100 bar. The process parameters were set at temperatures of 150 to $190{ }^{\circ} \mathrm{C}$ for 15 to $45 \mathrm{~min}$ since the condition reached. The heat was generated by an external heater (ceramic band heater Type CF400, Thermotech Co., Ltd) and controlled by a Type $\mathrm{K}$ thermocouple and PID instrument which connected to the reactor. The process was run by the batch operation. After the reaction was complete, the reactor was cooled to ambient temperature. The pretreated sample was washed, filtered using an ashless filter paper (Whatman, UK) and then dried in the oven at a constant temperature of $60{ }^{\circ} \mathrm{C}$ and stored at 4 ${ }^{\circ} \mathrm{C}$ prior to being analyzed. All of the experiment was conducted in triplicate.

\subsubsection{Enzymatic hydrolysis}

The experimental and analytical procedures for enzymatic hydrolysis was conducted based on the best condition of earlier work [7]. All of the treated and untreated coconut husk was hydrolyzed using commercial cellulase and $\mathrm{xy}$ lanase simultaneously. The activity of each enzyme used in this hydrolysis process was 18.6 $\mathrm{U}$ by mixing $9.530 \mathrm{~mL}$ cellulase and $3.857 \mathrm{ml}$ xylanase with the activity of 1.952 and 5.185 $\mathrm{U} / \mathrm{ml}$, respectively. The solid was run at $60^{\circ} \mathrm{C}$ and $125 \mathrm{rpm}$ in a modified incubator shaker.

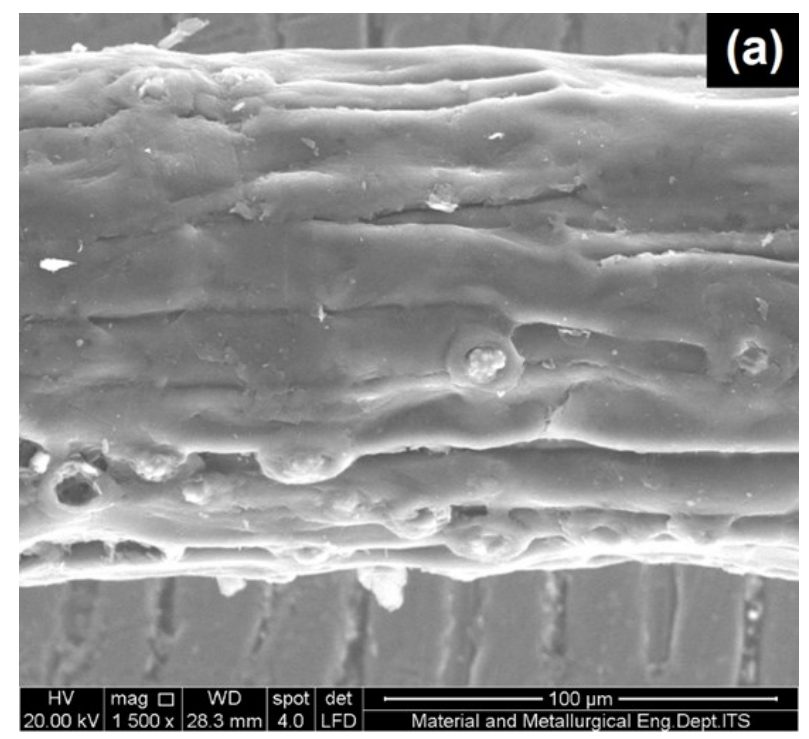

Reducing sugar concentration was analyzed every $4 \mathrm{~h}$ for $24 \mathrm{~h}$.

\subsubsection{Analytical and characterization methods}

The reducing sugar concentration of liquid obtained from SCW and enzymatic hydrolysis process were measured by using VisSpectrophotometer (CECIL 1001, Cambridge, United Kingdom) based on dinitro salicylic acid (DNS) method [31].

Solids of unpretreated and SCW-treated at optimum condition were characterized to investigate the chemical composition changes using the following analysis. Scanning Electron Microscopy (SEM) Evo MA 19 (Carl Zeiss, England) was utilized to visualize the qualitative alterations between solids. Fourier Transform Infrared (FT-IR) Nicolet iS10 (Thermo Electron Co., USA) was used to determine the deformation and solubilization process. Thermogravimetric (TG) SDT Q600 (TA Instrument, USA) was used to examine the thermal stability of samples. The last, X-Ray Diffraction (XRD) X'Pert PRO (PANalytical B.V, Netherlands) was conducted to determine the crystallinity index (CrI) which was calculated according to the following empirical Equation (1).

$$
C r I=\frac{I_{200}-I_{a m}}{I_{200}} \times 100
$$

where $I_{200}$ is the intensity of the 200 peak ( $2 \theta=$ $22.6^{\circ}$ ) and $I_{a m}$ is the intensity minimum between 200 and $110\left(2 \theta=18.7^{\circ}\right)$ peaks [32].

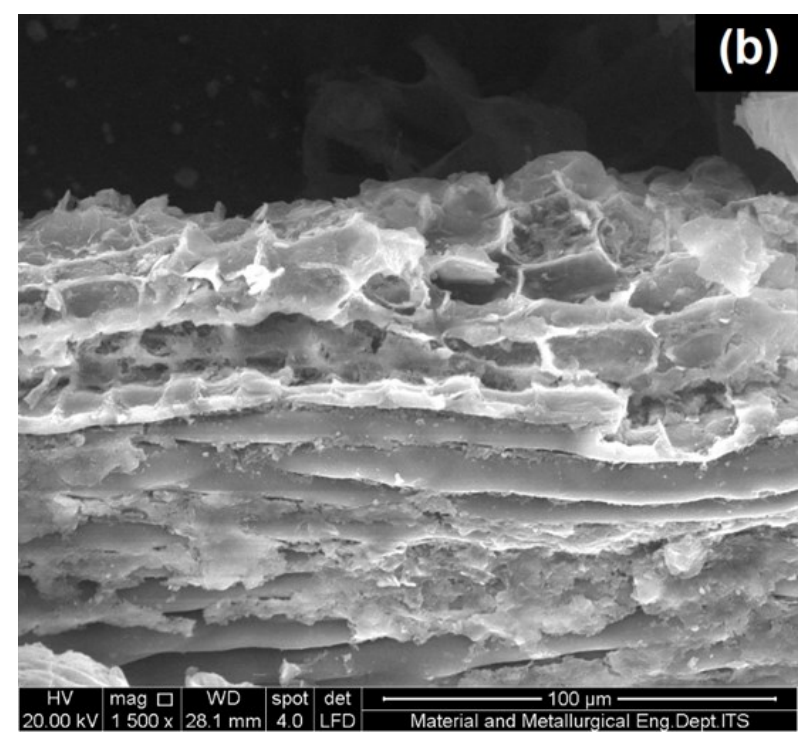

Figure 2. SEM images of (a) unpretreated and (b) SCW-treated solid. 


\subsubsection{Statistical analysis and calculations}

The significance level of the SCW process parameter was determined by applying the analysis of variance (ANOVA) at a 95\% confidence level utilizing Minitab 16 software package (Minitab Inc., ITS Surabaya, Indonesia). Sugar yield is calculated by Equation (2).

$$
\text { TRS yield }=\frac{\text { mass of reducing sugar obtained }(\mathrm{g})}{\text { mass of initial coconut husk }(\mathrm{g})} \times 100 \%
$$

\section{Results and Discussion}

\subsection{Structural Changes of Solids After SCW} Treatment

\subsubsection{SEM Analysis}

The surface morphology of untreated and SCW-treated solid was examined using SEM. Figure 2 shows the SEM images of (a) untreat-

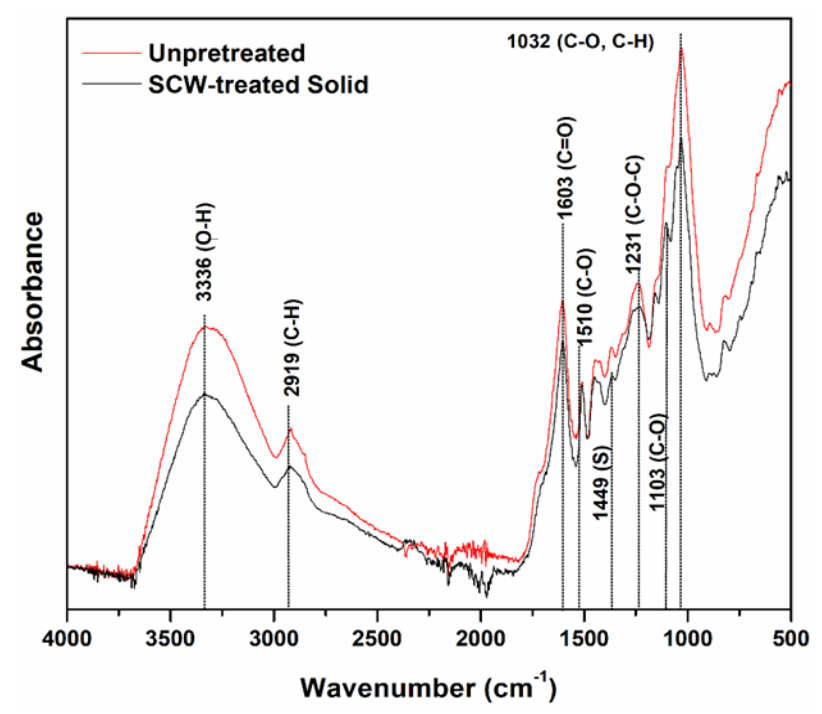

Figure 3. FTIR spectra of unpretreated and SCW-treated solid. ed and (b) SCW-treated solid at optimum conditions (80 bar, $150{ }^{\circ} \mathrm{C}$ and $40 \mathrm{~min}$ ). The figure reveals that the coconut husk was ruptured after SCW process. The breakage of this structure demonstrates that the SCW pretreatment could efficiently disintegrate lignocellulose cell wall, resulting in exposure of internal structure [33]. This crystal structural changes have been managed to expose cellulose to enzyme access and increase the digestibility of enzymatic hydrolysis [34].

\subsubsection{FTIR analysis}

The higher absorption intensity revealed the more functional groups in the solid samples [35]. The peak of several groups of the pretreated sample, such as $\mathrm{O}-\mathrm{H}$ (3336), C-H (2919), C=H (1603), C-O (1032), decreased in intensity compared to samples without pretreatment. Simultaneously, the new functional groups emerged at a wavenumber of $1449 \mathrm{~cm}^{-1}$ and $1103 \mathrm{~cm}^{-1}$.The FTIR spectra of untreated and SCW-treated sample are shown in Figure 3. The IR Bands summary refers to the previous report by Pandey [35] as shown in Table 1.

FTIR spectra exhibit a hydrogen-bonded O-H stretching absorption and $\mathrm{C}-\mathrm{H}$ stretching absorption around $3336 \mathrm{~cm}^{-1}$ and $2919 \mathrm{~cm}^{-1}$, respectively. These indicate that the $\mathrm{O}-\mathrm{H}$ and $\mathrm{C}-\mathrm{H}$ bonding of lignocellulose diminished after SCW applied. The bands at $1603 \mathrm{~cm}^{-1}$ and 1510 $\mathrm{cm}^{-1}$ show $\mathrm{C}=\mathrm{O}$ stretching of lignin and $\mathrm{C}-\mathrm{O}$ stretching of hemicellulose, respectively. It is related to the vibration of the aromatic ring of lignin and hemicellulose. Interestingly, the new band of $\mathrm{C}-\mathrm{O}$ (at $1449 \mathrm{~cm}^{-1}$ ) and $\mathrm{C}-\mathrm{H}$ (at $1103 \mathrm{~cm}^{-1}$ ) only appeared in the pretreated solid indicating the presence of syringyl (S) and guaiacyl $(G)$ units as the primary substructures of lignin, representing lignin degradation

Table 1. Identification of group bonds from FTIR diffraction

\begin{tabular}{|c|c|c|c|c|}
\hline \multicolumn{2}{|c|}{ Unpretreated } & \multicolumn{2}{|c|}{ SCW-treated } & \multirow{2}{*}{ Assignment } \\
\hline Band Position & Absorbance & Band Position & Absorbance & \\
\hline 3330 & 0.088 & 3336 & 0.063 & $\mathrm{O}-\mathrm{H}$ stretch \\
\hline 2916 & 0.054 & 2919 & 0.040 & C-H stretching \\
\hline 1605 & 0.096 & 1603 & 0.080 & $\begin{array}{l}\text { Aromatic skeletal vibration }+\mathrm{C}= \\
\mathrm{O} \text { stretching }\end{array}$ \\
\hline \multirow[t]{2}{*}{1508} & 0.069 & 1510 & 0.066 & Aromatic skeletal vibration \\
\hline & & 1449 & 0.069 & $\mathrm{C}-\mathrm{O}$ of syringyl $(\mathrm{S}) \mathrm{ring}$ \\
\hline \multirow[t]{2}{*}{1239} & 0.103 & 1231 & 0.092 & $\mathrm{C}-\mathrm{O}$ of guaiacyl (G) ring \\
\hline & & 1103 & 0.122 & Guaiacyl C-H and syringyl C-H \\
\hline 1031 & 0.195 & 1032 & 0.155 & $\begin{array}{l}\mathrm{C}-\mathrm{O} \text { primary alcohol, guaiacyl } \\
\text { (G) } \mathrm{C}-\mathrm{H}\end{array}$ \\
\hline
\end{tabular}


after SCW applied [28,36]. In addition, the decrease of absorbance of $\mathrm{C}-\mathrm{O}\left(\right.$ at $\left.1231 \mathrm{~cm}^{-1}\right)$ and $\mathrm{C}-\mathrm{H}\left(\right.$ at $\left.1032 \mathrm{~cm}^{-1}\right)$ revealed that SCW also removed the guaiacyl units [35]. The difference of band intensities indicates the deformation of lignin and solubilization of both hemicellulose and cellulose after pretreatment proses.

\subsubsection{TG Analysis}

Ciftci and Saldana [37] reported that the degradation of lignocellulosic biomass was divided into 4 different temperature ranges: $<220$ ${ }^{\circ} \mathrm{C}, 220-315{ }^{\circ} \mathrm{C}, 315-400{ }^{\circ} \mathrm{C}$, and $>400{ }^{\circ} \mathrm{C}$ for moisture, hemicelluloses, cellulose, and lignin decomposition, respectively. Figure 4 shows weight losses at $220-315{ }^{\circ} \mathrm{C}$ for the untreated sample and treated sample $\left(80 \mathrm{bar}, 150^{\circ} \mathrm{C}\right.$ and $40 \mathrm{~min}$ ) were $22.69 \%$ and $14.4 \%$, respectively. From the TG curve, treated solid also showed higher thermal stability compared to the untreated one. Untreated solid started to decompose at around $200{ }^{\circ} \mathrm{C}$ while the SCW-treated coconut husk started at about $250{ }^{\circ} \mathrm{C}$. These differences indicated that due to the high removal of lignin, SCW-treated sample contains more massive crystalline structure which requires higher decomposition temperature [38].

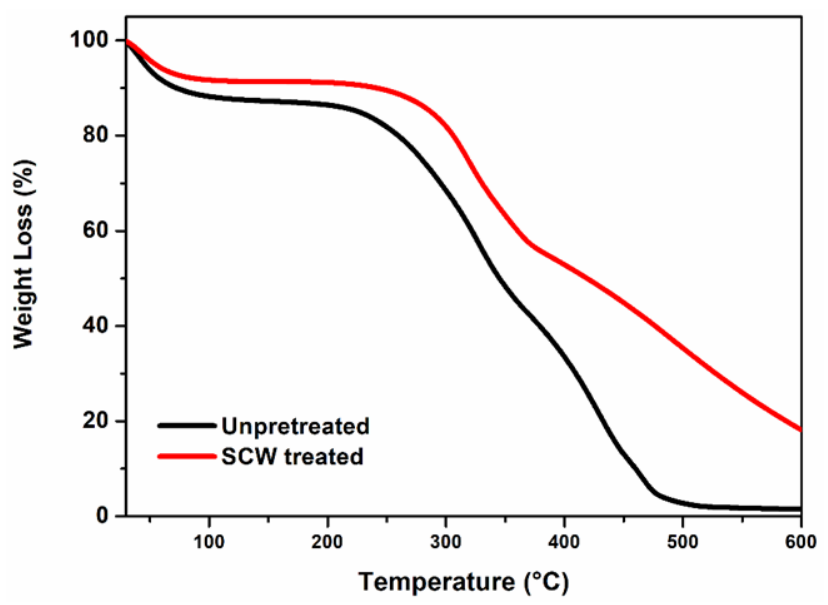

Figure 4. Thermo-gravimetric curves of unpretreated and SCW-treated solid.

\subsubsection{XRD Analysis}

Figure 5 shows a comparison of the diffraction patterns between untreated and SCWtreated coconut husk at $80 \mathrm{bar}, 150{ }^{\circ} \mathrm{C}$ and 40 min. The SCW-treated coconut husk showed a broad diffraction pattern with higher intensity compared to the untreated coconut husk. CrI value increased from 39.75 to $52.79 \%$. Ciftci and Saldana [37] reported that the crystalline index of sweet blue lupin increased from $11.5 \%$ to $58.6 \%$ after SCW pretreatment. Mohan et al. [39] also reported the crystalline index of the sample increased from $50.55 \%$ to $65.83 \%$ after pretreatment. This can be explained by the degradation of amorphous lignin and hemicellulose after SCW pretreatment, leading to an increase in the amount of crystalline part from cellulose enriched residue [40].

\subsection{Reducing Sugar Obtained after SCW Pro- cess.}

Besides changing the biomass solid, SCW also hydrolyzed the polymeric structure of holocellulose to oligomeric/ monomeric sugar, which commonly called reducing sugar. This sugar can be fermented into biofuel by microor-

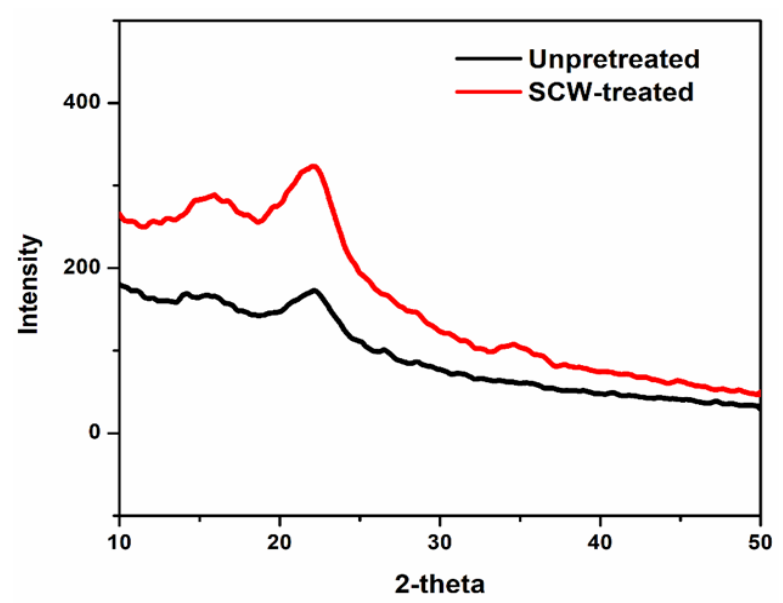

Figure 5. X-ray diffraction of unpretreated and SCW-treated solid.

Table 2. ANOVA of SCW parameter effect on sugar yield after SCW process.

\begin{tabular}{lrrrrr}
\hline Source & DF & Adj SS & Adj MS & F-Value & P-Value \\
\hline Temperature $\left({ }^{\circ} \mathrm{C}\right)$ & 2 & 206.47 & 103.233 & 23.69 & $\mathbf{0 . 0 0 0}$ \\
Time (min) & 2 & 160.46 & 80.230 & 18.41 & $\mathbf{0 . 0 0 0}$ \\
Pressure (bar) & 2 & 29.86 & 14.931 & 3.43 & 0.053 \\
Error & 20 & 87.17 & 4.358 & & \\
\hline Total & 26 & 483.95 & & & \\
\hline
\end{tabular}

Note. The bold letter denoted that the values are significant at $95 \%$ confidence level. 
yield of xylose increased first, and then decreased gradually. From the result, by increasing reaction time, the biomass solubility increased until reached the maximum liquefaction degree and subsequently degraded.

At the pressure of 100 bar, all of the SCW temperature condition, sugar yield decreased notably during $60 \mathrm{~min}$, producing the low sugar yield (see Figure 6c). These yield decreases may
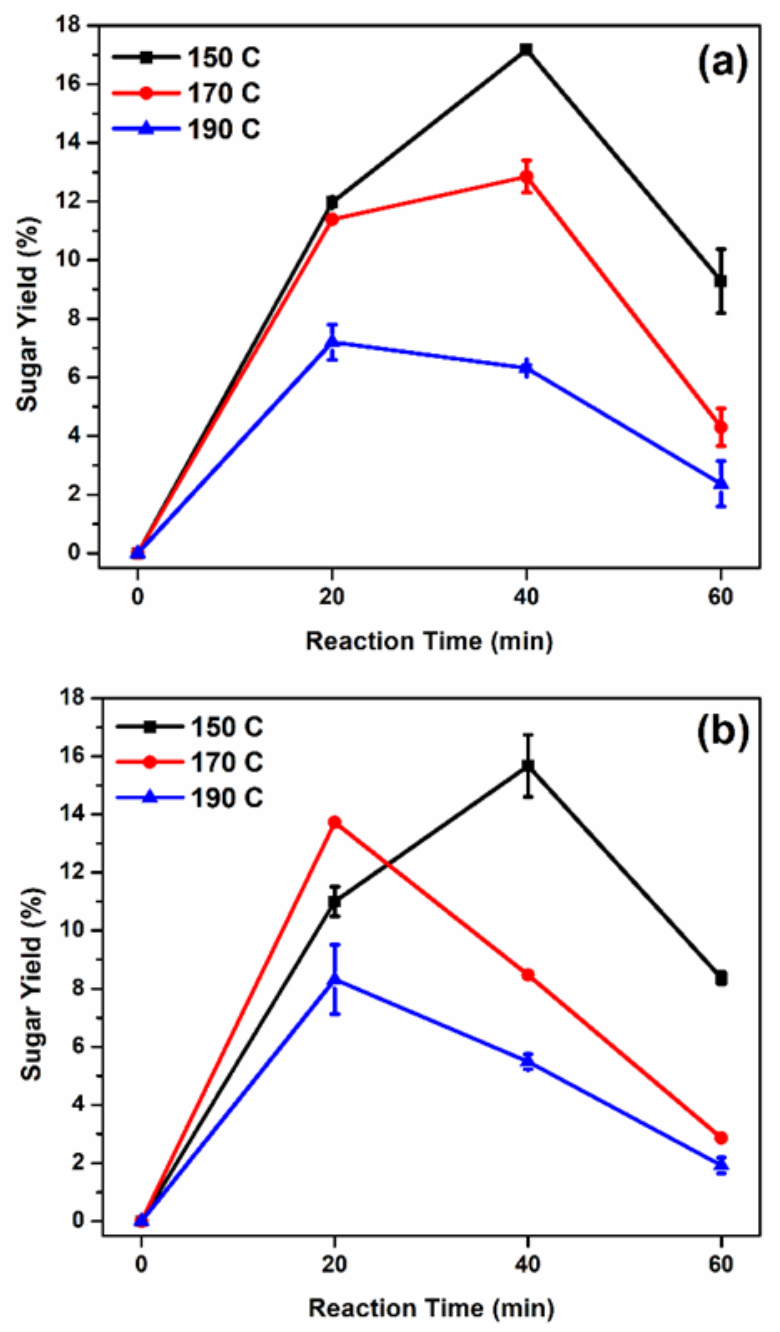

due to the degradation of monomeric sugar obtained after SCW process after treated at the severe condition. The monomers are not stable under high severity and simultaneously degraded, resulting in the formation of fermentation inhibitors that were not measured in this study $[19,43]$. Degradation products which may be found in the hydrolysates during subcritical water hydrolysis may include furan-derivatives (furfural and 5-hydroxy-methylfurfural (5HMF)) emerging from the transformation of pentose and hexose sugars found in cellulose and hemicellulose fractions, and phenoliccompounds appearing from lignin degradation such as vanillin and syringaldehyde [10,44]. Khuwijitjaru et al. [45] revealed that exceeding SCW treatment duration resulted in the gradual decrease of the product of coconut meal hydrolysis.

3.3 SCW Effect Towards Enzymatic Hydrolysis Performance

Generally, on the enzymatic hydrolysis of SCW-treated solid, the sugar yield increased significantly from 0 to $4 \mathrm{~h}$ of hydrolysis time

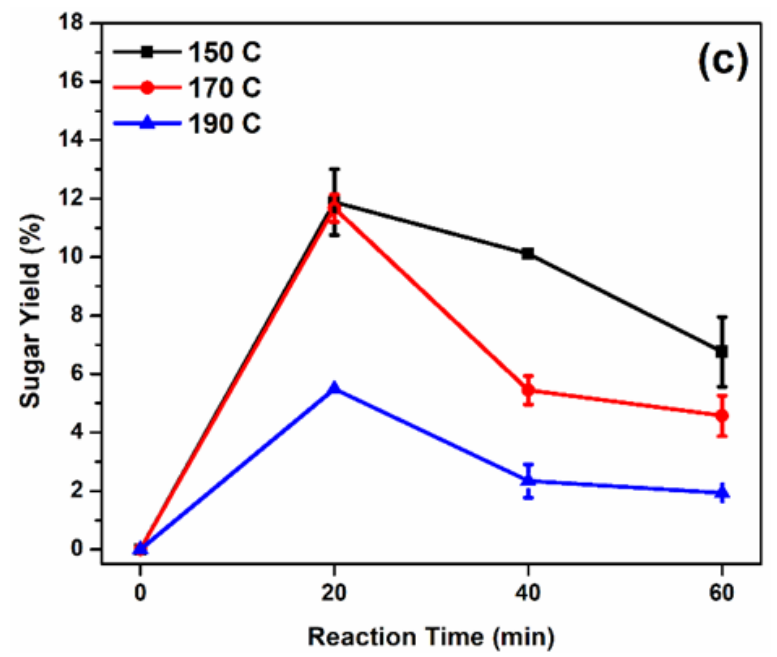

Figure 6. The effect of the operating condition of the SCW process at a constant pressure of (a) 60 bar, (b) 80 bar, and (c) 100 bar toward the reducing sugar yield.

Table 3. ANOVA of SCW parameter effect on sugar yield after enzymatic hydrolysis.

\begin{tabular}{lcrrrr}
\hline Source & Degree of freedom & Adj. SS & Adj. MS & F-Value & P-Value \\
\hline Temperature $\left({ }^{\circ} \mathrm{C}\right)$ & 2 & 0.4779 & 0.2389 & 0.27 & 0.767 \\
Time (min) & 2 & 4.8275 & 2.4138 & 2.71 & 0.091 \\
Pressure (bar) & 2 & 12.4829 & 6.2414 & 7.02 & $\mathbf{0 . 0 0 5}$ \\
Error & 20 & 17.7851 & 0.8893 & & \\
\hline Total & 26 & 35.5733 & & & \\
\hline
\end{tabular}

Note. The bold letter denoted that the values are significant at $95 \%$ confidence level. 
ganisms. The results show that the amount of sugar was affected by the operating condition of the SCW process. Analyzed by ANOVA, both time and temperature have a significant effect on sugar yield obtained following SCW treatment $(\mathrm{P}>0.05)$ (see Table 2). On the contrary, pressure has no significant effect on sugar production $(\mathrm{P}<0.05)$. These results were an agreement with the previous study using $\mathrm{CO}_{2}$ as pressurizing gas $[29,30]$. Among these factors, the pressure is the only factor which does not affect the sugar yield. Maintaining high pressure is only intended to avoid phase transition during the subcritical condition. Based on this analysis, the yield obtained following SCW treatment was plotted at constant pressure (see Figure 6).

Figure 6a shows the effect of temperature, time and pressure of SCW toward the sugar yield obtained after SCW process at a constant pressure of 60 bar. As depicted in Figure 6a, following pretreated at 150 and $170{ }^{\circ} \mathrm{C}$, sugar yield increased remarkably during $40 \mathrm{~min}$ of
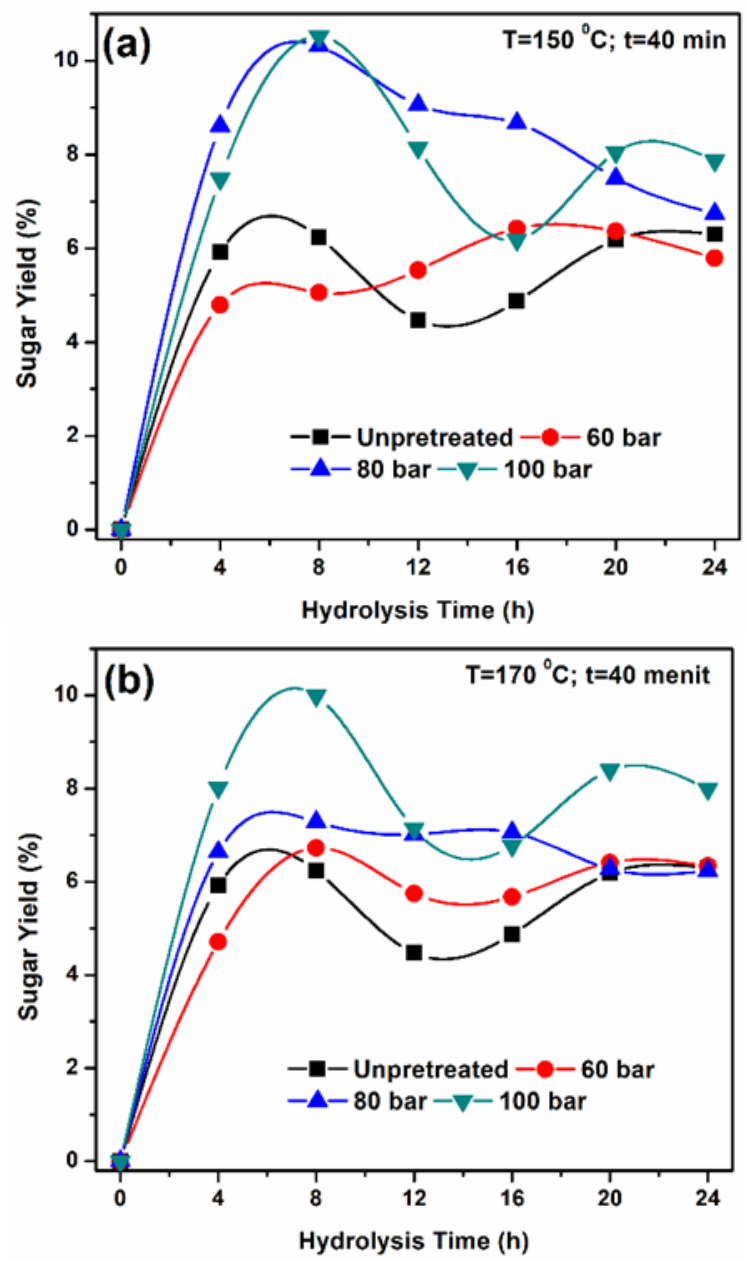

reaction time and then decreased significantly by prolonging reaction time. On the other hand, after pretreated at $190{ }^{\circ} \mathrm{C}$, sugar yield decreased significantly after only $20 \mathrm{~min}$ of reaction time. The temperature increase in a similar reaction time led to a decrease in sugar production. These phenomena revealed that the increase/decrease in sugar yield was related to the severity condition of the SCW process. In the previous work, it has been reported that total sugar yield trend in the extracts during $\mathrm{SCW}$ assisted by $\mathrm{CO}_{2}$ of $\mathrm{CCH}$ firstly increased under low severity and then decreased sharply at high severity [29]. The similar trend of sugar produced was reported by Weiqi et al. [41]. Elevating the temperature resulted in a rapid decrease of total xylose yield which was attributed to the degradation of xylose into furfural under critical condition. The highest sugar yield by $17.18 \%$ was gained at operating condition of $150{ }^{\circ} \mathrm{C}$ and 60 bar for 40 min which refers to the mild condition of SCW.

Figure $6 \mathrm{~b}$ shows the effect of SCW operating condition toward the sugar yield at a pressure of 80 bar. Heated at $150^{\circ} \mathrm{C}$, the sugar yield obtained after treated at 80 bar had a same trend as treated at 60 bar (Figure 6a). On the other hand, heated at 170 and $190{ }^{\circ} \mathrm{C}$, sugar yield increased dramatically during the early $20 \mathrm{~min}$ of reaction and reached the maximum yield of 13.72 and $8.32 \%$, respectively. However, prolonging the reaction time would decrease sugar yield gradually. The dramatical increase of sugar yield might be due to fast decomposition rate of hemicellulose on the high temperature. These phenomena may be attributed to the amorphous nature of hemicellulose structure [39]. Hongdan et al. [42] reported that by the longer pretreatment time from 0 to $40 \mathrm{~min}$, the

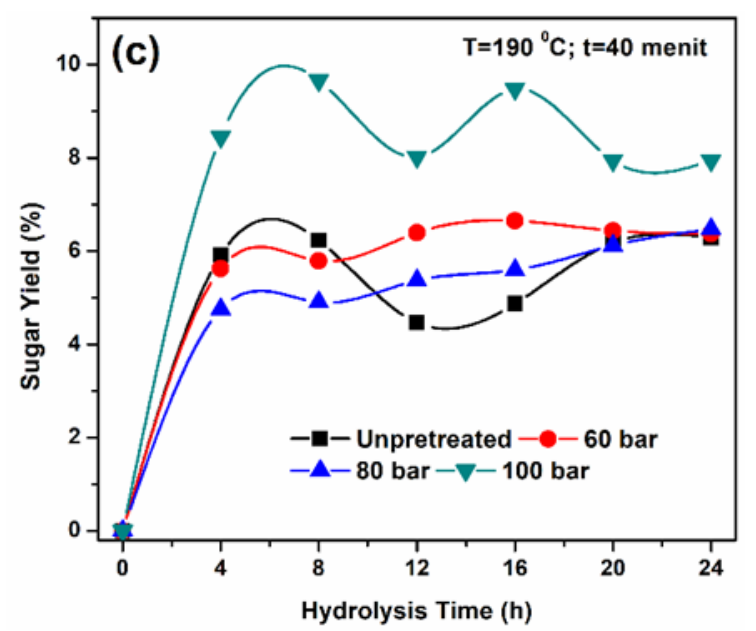

Figure 7. Time course of the sugar yield on enzymatic hydrolysis of SCW-treated solid at operating condition of (a) 150 , (b) 170 , and (c) $190^{\circ} \mathrm{C}$ for $40 \mathrm{~min}$. 

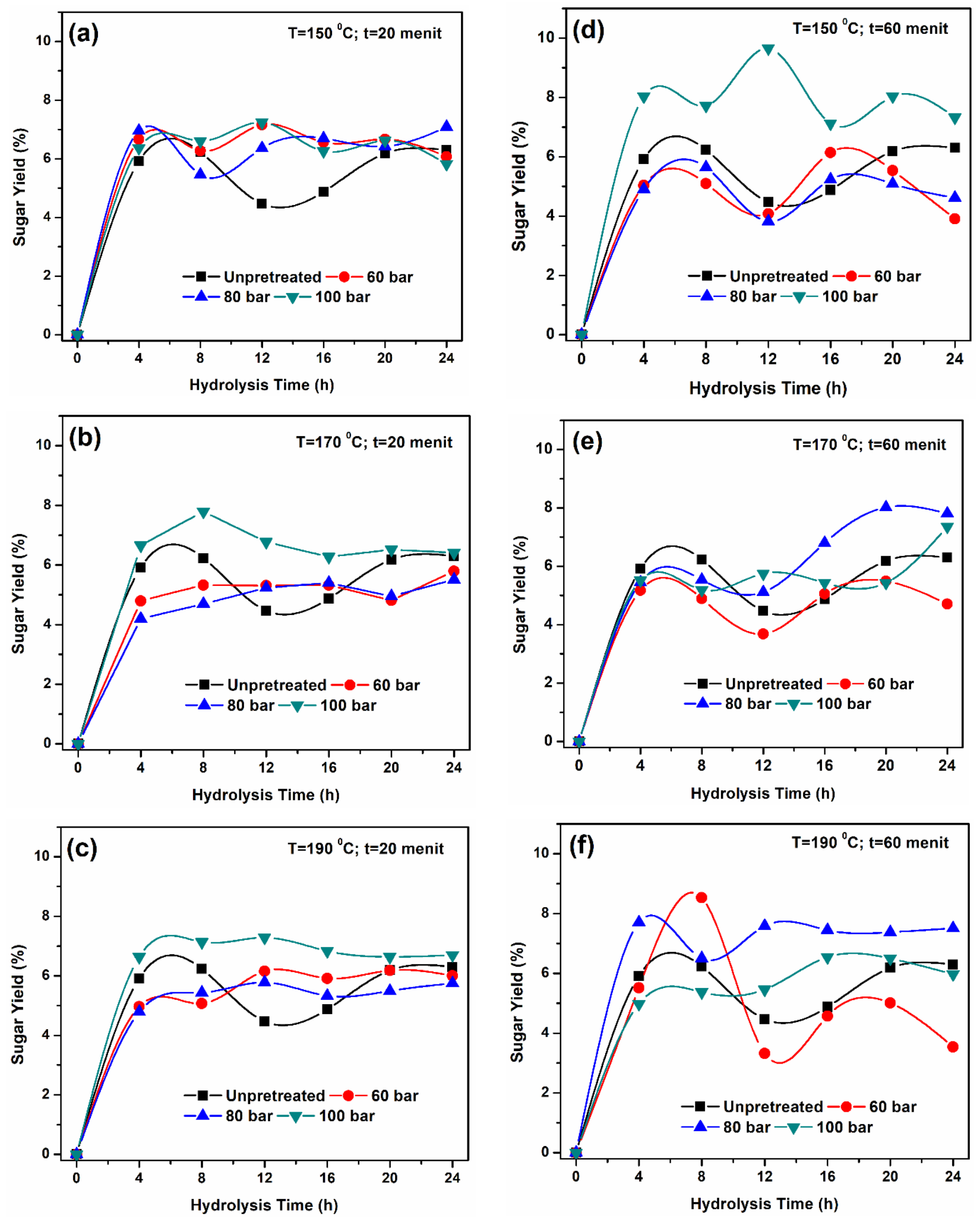

Figure 8. Time course of the sugar yield on enzymatic hydrolysis of SCW-treated solid at operating condition of $20 \mathrm{~min}(\mathrm{a}-\mathrm{c})$ and $60 \mathrm{~min}(\mathrm{~d}-\mathrm{f})$. 
(see Figure 7). The maximum sugar yield was obtained at early $8 \mathrm{~h}$ of hydrolysis time and then decreased/ tended to be constant exceed 8 $\mathrm{h}$. The phenomenon was confirmed by SanchezRamirez [46]. They showed that the enzyme activity decreased continually at $60^{\circ} \mathrm{C}$ incubation after $6 \mathrm{~h}$ of enzymatic hydrolysis.

Figure 7 shows the time course of sugar yield on the enzymatic hydrolysis of SCWtreated solid at various temperature for $40 \mathrm{~min}$ of SCW reaction time. The figure was plotted based on the significance of SCW factor that gave a positive impact to the enzymatic hydrolysis. Using ANOVA, it is known that the pressure of SCW gave a significant effect on sugar obtained after enzymatic hydrolysis (see Table 3). As shown in Figure 7(a-c), enzymatic hydrolysis of solid which treated by SCW at high pressure gave a significant increase in the sugar yield compared to unpretreated solid. Pressurized at 100 bar, hydrolysis of the solid treated at 170 and $190{ }^{\circ} \mathrm{C}$ gave the highest sugar yield of all SCW treatment conditions. On the other hand, treated by low pressure, SCW treatment only gave a little increase in sugar yield. Sugar yield of solid treated at 60 and 80 bar have a similar result as untreated solid.
These results indicate that there was an increase in porosity of lignocellulose structure as the pressure increased. This high level of porosity allows more access for cellulase and xylanase enzyme to degrade cellulose and hemicellulose into reducing sugar [47]. Zhang and $\mathrm{Wu}$ [48] reported in their study that at constant temperature and time, there was an increase in reducing sugar yield obtained after enzymatic hydrolysis as the pressure increased. The highest yield of sugar during enzymatic hydrolysis was obtained on the solid which treated by SCW at $150{ }^{\circ} \mathrm{C}, 40 \mathrm{~min}$ and 100 bar, yielding reducing sugar of $10.52 \%$.

On the SCW reaction time of 20 and $60 \mathrm{~min}$ (Figure 8(a-f)), enzymatic hydrolysis of SCWtreated solid at high pressure (100 and 80 bar) also gave a significant increase in the sugar obtained compared to treated at low pressure (60 bar) and untreated solid at various severity condition. The lowest sugar yield was obtained at the lowest SCW pressure condition. These results exhibited a strong effect of SCW pressure that reflect significant positive changes of lignocellulose porosity on the direct enzymatic hydrolysis in SCW residues of coconut husk [47].

Table 4. Summary of sugar yield on SCW and enzymatic hydrolysis.

\begin{tabular}{|c|c|c|c|c|c|c|}
\hline \multicolumn{3}{|c|}{ Variable } & \multirow{2}{*}{$\mathrm{SF}$} & \multicolumn{3}{|c|}{ Sugar Yield (\%) } \\
\hline$P$ (bar) & $T\left({ }^{\circ} \mathrm{C}\right)$ & $t(\min )$ & & SCW & Enzymatic & Total \\
\hline 60 & 150 & 40 & 3.07 & 17.18 & 6.43 & 23.61 \\
\hline 80 & 150 & 40 & 3.07 & 15.67 & 10.31 & 25.98 \\
\hline 100 & 150 & 40 & 3.07 & 10.11 & 10.52 & 20.63 \\
\hline 80 & 150 & 60 & 3.25 & 8.36 & 5.24 & 13.60 \\
\hline 80 & 170 & 60 & 3.84 & 2.86 & 8.02 & 10.88 \\
\hline 80 & 190 & 60 & 4.43 & 1.92 & 7.58 & 9.50 \\
\hline 100 & 190 & 20 & 3.95 & 5.49 & 7.28 & 12.77 \\
\hline 100 & 190 & 40 & 4.25 & 2.34 & 9.66 & 12.90 \\
\hline 100 & 190 & 60 & 4.43 & 1.93 & 6.55 & 8.48 \\
\hline
\end{tabular}

Note. The bold letter denoted the highest value of the same column.

Table 5. Previous research of sugar yield.

\begin{tabular}{llcl}
\hline \multicolumn{1}{c}{ Pretreatment } & \multicolumn{1}{c}{ Operating condition } & $\begin{array}{c}\text { Total Sugar } \\
\text { Yield (\%) }\end{array}$ & \multicolumn{1}{c}{ References } \\
\hline $\mathrm{CO}_{2}$-Subcritical water & $208^{\circ} \mathrm{C}, 200 \mathrm{bar}, 30 \mathrm{~min}$ & 11.70 & Prado et al [4] \\
$\mathrm{N}_{2}$-Subcritical water & $140^{\circ} \mathrm{C}, 30 \mathrm{bar}, 215 \mathrm{~min}$ & 32.37 & Purnomo et al. $[50]$ \\
$\mathrm{CO}_{2}$-Subcritical water & $250^{\circ} \mathrm{C}, 200 \mathrm{bar}, 30 \mathrm{~min}$ & 13.50 & Prado et al. [26] \\
Steam Explosion & $150^{\circ} \mathrm{C}, 30 \mathrm{~min}, \mathrm{H}_{2} \mathrm{SO}_{4} 0.1 \%$ & 23.80 & Carvalho et al. [49] \\
Liquid Hot Water & $190^{\circ} \mathrm{C}, 45 \mathrm{~min}$ & 21.00 & Sabanci and Buyukkileci [14] \\
$\mathrm{CO}_{2}$-Subcritical water & $150^{\circ} \mathrm{C}, 80 \mathrm{bar}, 60 \mathrm{~min}$ & 20.64 & Muharja et al. [29] \\
$\mathrm{N}_{2}$-Subcritical water & $150^{\circ} \mathrm{C}, 80 \mathrm{bar}, 40 \mathrm{~min}$ & 25.98 & This study \\
\hline
\end{tabular}


Table 4 shows the summary of sugar yield obtained after the process of SCW and enzymatic hydrolysis at some severity factor conditions. It can be seen from the data that more extreme reaction condition of temperature and time of SCW tended to result in lower sugar yield after SCW process. In the case of enzymatic hydrolysis, the higher pressure of SCW gave a higher sugar yield in the low severity of the SCW process. The maximum total sugar yield of $25.98 \%$ was obtained at the mild condition of SCW treatment $\left(150{ }^{\circ} \mathrm{C}, 80 \mathrm{bar}\right.$, and 40 min). This condition was proportional to produce the optimum sugar yield from both SCW and enzymatic hydrolysis.

In this work, the maximum total sugar yield of $25.98 \%$ was higher than the results of various hydrothermal treatment method [14] (see Table 5). Besides the high yield, this method is more environmentally friendly than the method by Carvalho et al. [49] who used acid catalyst on the steam explosion treatment. Furthermore, the method promises a more economical process due to the use of nitrogen as pressurizing gas in SCW treatment compared to the other earlier works $[4,26,29]$. Finally, the result of this study is superior compared to the other study using $\mathrm{N}_{2}$-assisted subcritical water which used the lower operating condition [50].

\section{Conclusion}

Based on the findings reported in this study, it can be concluded that SCW assisted by nitrogen gas is a viable process to treat lignocellulose waste for biofuel production. This can be achieved by adjusting the operating condition of SCW treatment (temperature, pressure and time) in the mild condition, resulting in the best result of total sugar yield for both SCW and enzymatic hydrolysis process. The solid characterizations confirm that solid decomposition following SCW treatment assisted by $\mathrm{N}_{2}$ extremely succeed to boost the digestibility of the enzymatic hydrolysis process, which ensured the reliability of the process for commercial biofuel production.

\section{Acknowledgement}

This work was supported by the Directorate General of Resources for Science, Technology \& Higher Education, Ministry of Research, Technology and Higher Education of Republic Indo$\mathrm{n}$ e s i a ( G r a n t n u m b r 022817/IT2.VII/PN.0100/2018).

\section{References}

[1] Park, J., Riaz, A., Insyani, R., Kim, J. (2018). Understanding the relationship between the structure and depolymerization behavior of lignin. Fuel, 217, 202-210.

[2] Guo, H., Chang, Y., Lee, D. J. (2018). Enzymatic saccharification of lignocellulosic biorefinery: Research focuses. Bioresource Technology, 252, 198-215.

[3] Widjaja, A., Agnesty, S. Y., Sangian, H. F., Gunawan, S. (2015). Application of ionic liquid [DMIM]DMP pretreatment in the hydrolysis of sugarcane Bagasse for biofuel production. Bulletin of Chemical Reaction Engineering and Catalysis, 10(1), 70-77.

[4] Prado, J. M., Forster-Carneiro, T., Rostagno, M. A., Follegatti-Romero, L. A., Maugeri Filho, F., Meireles, M. A. A. (2014). Obtaining sugars from coconut husk, defatted grape seed, and pressed palm fiber by hydrolysis with subcritical water. Journal of Supercritical Fluids, 89, 89-98.

[5] Agustriyanto, R., Fatmawati, A., Liasari, Y. (2012). Study of enzymatic hydrolysis of dilute acid pretreated coconut husk. Bulletin of Chemical Reaction Engineering and Catalysis, 7(2), 137-141.

[6] Sangian, H. F., Kristian, J., Rahma, S., Dewi, H. K., Puspasari, D. A., Agnesty, S. Y., Gunawan, S., Widjaja, A. (2015). Preparation of reducing sugar hydrolyzed from high-lignin coconut coir dust pretreated by the recycled ionic liquid [mmim][dmp] and combination with alkaline. Bulletin of Chemical Reaction Engineering and Catalysis, 10(1): 8-22.

[7] Muharja, M., Umam, D. K., Pertiwi, D., Zuhdan, J., Nurtono, T., Widjaja, A. (2019). Enhancement of sugar production from coconut husk based on the impact of the combination of surfactant-assisted subcritical water and enzymatic hydrolysis. Bioresource Technology, 274, 89-96.

[8] Kumar, M., Olajire Oyedun, A., Kumar, A. (2018). A review on the current status of various hydrothermal technologies on biomass feedstock. Renewable and Sustainable Energy Reviews, 81, 1742-1770.

[9] Sekoai, P. T., Yoro, K. O., Bodunrin, M. O., Ayeni, A. O., Daramola, M. O. (2018). Integrated system approach to dark fermentative biohydrogen production for enhanced yield, energy efficiency and substrate recovery. $R e$ views in Environmental Science and Bio/Technology, 17(3), 501-529.

[10] Sivagurunathan, P., Kumar, G., Mudhoo, A., Rene, E. R., Saratale, G. D., Kobayashi, T., Xu, K., Kim, S.H., Kim, D. H. (2017). Fermentative hydrogen production using ligno- 
cellulose biomass: An overview of pretreatment methods, inhibitor effects and detoxification experiences. Renewable and Sustainable Energy Reviews, 77, 28-42.

[11] Wang, P., Chen, Y. M., Wang, Y., Lee, Y. Y., Zong, W., Taylor, S., McDonald, T., Wang, Y. (2019). Towards comprehensive lignocellulosic biomass utilization for bioenergy production: Efficient biobutanol production from acetic acid pretreated switchgrass with Clostridium saccharoperbutylacetonicum N1-4. Applied Energy, 236, 551-559.

[12] Matsakas, L., Raghavendran, V., Yakimenko, O., Persson, G., Olsson, E., Rova, U., Olsson, L., Christakopoulos, P. (2019). Lignin-first biomass fractionation using a hybrid organosolv - Steam explosion pretreatment technology improves the saccharification and fermentability of spruce biomass. Bioresource Technology, 273, 521-528.

[13] Gonzales, R. R., Kim, S.-H. (2017). Dark fermentative hydrogen production following the sequential dilute acid pretreatment and enzymatic saccharification of rice husk. International Journal of Hydrogen Energy. 42, 27577 27583.

[14] Sabanci, K., Buyukkileci, A. O. (2018). Comparison of liquid hot water, very dilute acid and alkali treatments for enhancing enzymatic digestibility of hazelnut tree pruning residues. Bioresource Technology, 261, 158-165.

[15] Sarkar, N., Ghosh, S. K., Bannerjee, S., Aikat, K. (2012). Bioethanol production from agricultural wastes: An overview. Renewable Energy, 37(1), 19-27.

[16] Ahmad, F., Silva, E. L., Varesche, M. B. A. (2018). Hydrothermal processing of biomass for anaerobic digestion - A review. Renewable and Sustainable Energy Reviews, 98, 108124 .

[17] Ashraf, M. T., Schmidt, J. E. (2018). Process simulation and economic assessment of hydrothermal pretreatment and enzymatic hydrolysis of multi-feedstock lignocellulose Separate vs combined processing. Bioresource Technology, 249, 835-843.

[18] Okajima, I., Sako, T. (2014). Energy conversion of biomass with supercritical and subcritical water using large-scale plants. Journal of Bioscience and Bioengineering, 117(1), 1-9.

[19] Jönsson, L. J., Martín, C. (2016). Pretreatment of lignocellulose: Formation of inhibitory by-products and strategies for minimizing their effects. Bioresource Technology, 199, 103-112.

[20] Martín, C., Wu, G., Wang, Z., Stagge, S., Jönsson, L. J. (2018). Formation of microbial inhibitors in steam-explosion pretreatment of softwood impregnated with sulfuric acid and sulfur dioxide. Bioresource Technology, 262, 242-250.

[21] Mayanga-Torres, P. C., Lachos-Perez, D., Rezende, C. A., Prado, J. M., Ma, Z., Tompsett, G. T., Timko, M. T., Forster-Carneiro, T. (2017). Valorization of coffee industry residues by subcritical water hydrolysis: Recovery of sugars and phenolic compounds. Journal of Supercritical Fluids, 120, 75-85.

[22] Abaide, E. R., Ugalde, G., Di Luccio, M., Moreira, R. de F. P. M., Tres, M. V, Zabot, G. L., Mazutti, M. A. (2019). Obtaining fermentable sugars and bioproducts from rice husks by subcritical water hydrolysis in a semicontinuous mode. Bioresource Technology, $272,510-520$.

[23] Kubota, A. M., Kalnins, R., Overton, T. W. (2018). A biorefinery approach for fractionation of Miscanthus lignocellulose using subcritical water extraction and a modified organosolv process. Biomass and Bioenergy, 111, 52-59.

[24] Monlau, F., Sambusiti, C., Barakat, A., Quéméneur, M., Trably, E., Steyer, J., Carrère, $H$. (2014). Do furanic and phenolic compounds of lignocellulosic and algae biomass hydrolyzate inhibit anaerobic mixed cultures? A comprehensive review. Biotechnology Advances, 32(5), 934-951.

[25] Batista, G., Souza, R. B. A., Pratto, B., dos Santos-Rocha, M. S. R., Cruz, A. J. G. (2019). Effect of severity factor on the hydrothermal pretreatment of sugarcane straw. Bioresource Technology, 275, 321-327.

[26] Prado, J. M., Vardanega, R., Nogueira, G. C., Forster-Carneiro, T., Rostagno, M. A., Maugeri Filho, F., Meireles, M. A. A. (2017). Valorization of Residual Biomasses from the Agri-Food Industry by Subcritical Water Hydrolysis Assisted by $\mathrm{CO}_{2}$. Energy and Fuels, 31(3), 2838-2846.

[27] Yang, T., Wang, J., Li, B., Kai, X., Li, R. (2017). Effect of residence time on two-step liquefaction of rice straw in a $\mathrm{CO} 2$ atmosphere: Differences between subcritical water and supercritical ethanol. Bioresource Technology, 229, 143-151.

[28] Öztürk, I., Irmak, S., Hesenov, A., Erbatur, O. (2010). Hydrolysis of kenaf (Hibiscus cannabinus L.) stems by catalytical thermal treatment in subcritical water. Biomass and Bioenergy, 34(11), 1578-1585.

[29] Muharja, M., Junianti, F., Ranggina, D., Nurtono, T., Widjaja, A. (2018). An integrated green process: Subcritical water, enzymatic hydrolysis, and fermentation, for biohydrogen production from coconut husk. Bioresource Technology, 249, 268-275. 
[30] Muharja, M., Junianti, F., Nurtono, T., Widjaja, A. (2017). Combined subcritical water and enzymatic hydrolysis for reducing sugar production from coconut husk. AIP Conference Proceedings, 1840(1), 30004.

[31] Datta, R. (1981). Acidogenic fermentation of corn stover. Biotechnology and Bioengineering, 23(1), 61-77.

[32] Jiang, F., Hsieh, Y.-L. (2014). Super water absorbing and shape memory nanocellulose aerogels from TEMPO-oxidized cellulose nanofibrils via cyclic freezing-thawing. Journal of Materials Chemistry A, 2(2), 350-359.

[33] Sangian, H. F., Widjaja, A. (2017). Effect of Pretreatment Method on Structural Changes of Coconut Coir Dust. BioResources, 12(4), 8030-8046.

[34] Sangian, H. F., Ranggina, D., Ginting, G. M., Purba, A. A., Gunawan, S., Widjaja, A. (2015). Study of the preparation of sugar from highlignin lignocellulose applying subcritical water and enzymatic hydrolysis: Synthesis and consumable cost evaluation. Scientific Study and Research: Chemistry and Chemical Engineering, Biotechnology, Food Industry, 16(1), 13-27.

[35] Pandey, K. K. (1999). A study of chemical structure of soft and harwood and wood polymers by FTIR spectrscopy. Journal of Applied Polymer Science, 71, 1969-1975.

[36] Xu, F., Yu, J., Tesso, T., Dowell, F., Wang, D. (2013). Qualitative and quantitative analysis of lignocellulosic biomass using infrared techniques: A mini-review. Applied Energy, 104, 801-809.

[37] Ciftci, D., Saldaña, M. D. A. (2015). Hydrolysis of sweet blue lupin hull using subcritical water technology. Bioresource Technology, 194, 75-82.

[38] Cui, F. M., Zhang, X. Y., Shang, L. M. (2013). Thermogravimetric Analysis of Glucose-Based and Fructose-Based Carbohydrates. Advanced Materials Research, 805-806, 265-268.

[39] Mohan, M., Banerjee, T., Goud, V. V. (2015). Hydrolysis of bamboo biomass by subcritical water treatment. Bioresource Technology, $191,244-252$.

[40] Imman, S., Laosiripojana, N., Champreda, V. (2018). Effects of Liquid Hot Water Pretreatment on Enzymatic Hydrolysis and Physicochemical Changes of Corncobs. Applied Biochemistry and Biotechnology, 184, 432-443.

[41] Weiqi, W., Shubin, W., Liguo, L. (2013). Combination of liquid hot water pretreatment and wet disk milling to improve the efficiency of the enzymatic hydrolysis of eucalyptus. Bioresource Technology, 128, 725-730.
[42] Hongdan, Z., Shaohua, X., Shubin, W. (2013). Enhancement of enzymatic saccharification of sugarcane bagasse by liquid hot water pretreatment. Bioresource Technology, 143, 391396.

[43] Sun, S., Sun, S., Cao, X., Sun, R. (2016). The role of pretreatment in improving the enzymatic hydrolysis of lignocellulosic materials. Bioresource Technology, 199, 49-58.

[44] Fernández, M. A., Rissanen, J., Nebreda, A. P., Xu, C., Willför, S., Serna, J. G., Salmi, T., Grénman, H. (2018). Hemicelluloses from stone pine, holm oak, and Norway spruce with subcritical water extraction - comparative study with characterization and kinetics. Journal of Supercritical Fluids, 133, 647657.

[45] Khuwijitjaru, P., Watsanit, K., Adachi, S. (2012). Carbohydrate content and composition of product from subcritical water treatment of coconut meal. Journal of Industrial and Engineering Chemistry, 18(1), 225-229.

[46] Sánchez-Ramírez, J., Martínez-Hernández, J. L., Segura-Ceniceros, P., López, G., Saade, H., Medina-Morales, M. A., Ramos-González, R., Aguilar, C. N., Ilyina, A. (2017). Cellulases immobilization on chitosan-coated magnetic nanoparticles: application for Agave Atrovirens lignocellulosic biomass hydrolysis. Bioprocess and Biosystems Engineering, 40(1), 922.

[47] Sun, D., Alam, A., Tu, Y., Zhou, S., Wang, Y., Xia, T., Huang, J., Li, Y., Zahoor, Wei, X., Hao, B., Peng, L. (2017). Steam-exploded biomass saccharification is predominately affected by lignocellulose porosity and largely enhanced by Tween-80 in Miscanthus. Bioresource Technology, 239, 74-81.

[48] Zhang, H., Wu, S. (2013). Subcritical $\mathrm{CO}_{2}$ pretreatment of sugarcane bagasse and its enzymatic hydrolysis for sugar production. Bioresource Technology, 149, 546-550.

[49] Carvalho, A. F. A., Marcondes, W. F., de Oliva Neto, P., Pastore, G. M., Saddler, J. N., Arantes, V. (2018). The potential of tailoring the conditions of steam explosion to produce xylo-oligosaccharides from sugarcane bagasse. Bioresource Technology, 250, 221-229.

[50] Purnomo, A., Yudiantoro, Y. A. W., Putro, J. N., Nugraha, A. T., Irawaty, W., Ismadji, S. (2016). Subcritical water hydrolysis of durian seeds waste for bioethanol production. International Journal of Industrial Chemistry, 7(1), 29-37. 